Competence: Dournal of Management Studies.

Vol 15, No 2, Oktober 2021

ISSN: 2541-2655 (Online) dan ISSN: 1907-4824 (Print)

\title{
CITRA MEREK DAN PROMOSI TERHADAP KEPUTUSAN PEMBELIAN PRODUK DI MASA PANDEMI COVID-19 (STUDI KASUS BS COFFEE \& DONUTS)
}

\author{
Mila Camelia ${ }^{1}$, Budi Hartono ${ }^{2}$ \\ helenamila11@gmail.com, hartono.budi@untidar.ac.id \\ Universitas Tidar
}

\begin{abstract}
ABSTRAK
Mempertahankan suatu usaha bukanlah hal yang mudah ditengah persaingan yang ketat dan adanya permasalahan yang timbul akibat sesuatu yang tidak terduga seperti bencana alam yang sedang dihadapi hampir seluruh bidang usaha di dunia yaitu permasalah yang timbul akibat pandemi covid-19 yang menimpulkan adanya peraturan pemerintah dalam pembatasan sosial dan juga adanya penurunan daya beli masyarakat yang juga mempengaruhi pendapatan suatu usaha. Untuk menghadapi itu sangat penting bagi seorang wirausaha untuk menetapkan strategi yang tepat untuk mempertahankan usahnya. Objek dalam penelitian ini adalah BS Coffee \& Donuts yang mana cafe tersebut masih mampu bertahan dan menjalankan usaha ditengah pandemi covid-19 dan ketat persaingan terbukti dengan tidak pernah sepinya pengunjung yang melakukan pesanan dine-in maupun take away. Metode penelitian ini adalah analisis deskriptif. Populasi dalam penelitian ini adalah orang yang pernah mengkonsumsi produk BS Coffee \& Donuts dan bersedia untuk mengisi kuisioner yang disebarkan oleh peneliti. Penentuan sample pada penelitian ini didasarkan pada dua kriteria yaitu orang yang pernah membeli produk BS Coffee \& Donuts yang berjumlah 41 orang. Hasil penelitian ini menyatakan bahwa variabel citra merek dan promosi merupakan faktor yang mempengaruhi keputusan pembelian konsumen BS Coffee \& Donuts.

Kata Kunci: citra merek, promosi, keputusan pembelian, usaha, wirausaha, bencana alam
\end{abstract}

\begin{abstract}
Maintaining a business is not easy in the midst of intense competition and there are problems that arise due to something unexpected such as natural disasters that are being faced by almost all business fields in the world, namely problems that arise due to the covid-19 pandemic which has led to government regulations in social restrictions. and also a decrease in people's purchasing power which also affects the income of a business. To deal with it, it is very important for an entrepreneur to set the right strategy to maintain his business. The object in this research is BS Coffee \& Donuts, where the cafe is still able to survive and run a business in the midst of the covid-19 pandemic and tight competition as evidenced by the never empty visitors who order dine-in and take away. This research method is descriptive analysis. The population in this study were people who had consumed BS Coffee \& Donuts products and were willing to fill out the questionnaire distributed by the researcher. Determination of the sample in this study is based on two criteria, namely people who have bought BS Coffee \& Donuts products,
\end{abstract}


amounting to 41 people. The results of this study indicate that brand image and promotion variables are factors that influence consumer purchasing decisions for BS Coffee \& Donuts.

Keywords: brand image, promotion, purchase decision, business, entrepreneurship, natural disaster

\section{PENDAHULUAN}

Keberhasilan suatu usaha dilihat dari seberapa lama usaha tersebut untuk mampu bertahan. Mempertahankan suatu usaha bukanlah hal yang mudah, ada banyak permasalahan yang perlu dilewati. Permasalahan tersebut dapat berasal dari faktor internal maupun faktor eksternal. Permasalahan dalam suatu usaha yang berasal dari faktor internal yang dapat mengancam keberlangsungan suatu usaha dapat bersal dari sumber daya manusianya seperti sifat kepemimpinanan yang buruk, adanya korupsi dll. Sedangkan permasalahan yang berasal faktor ekternal suatu usaha dapat berasal dari adanya peraturan pemerintah yang merugikan, ketatnya persaingan dan bencana alam. Pada saat ini bencana alam yang sedang dihadapi hampir seluruh bidang usaha di dunia yaitu permasalah yang timbul akibat pandemi covid-19.

Menurut World Health Organization (WHO) covid-19 merupakan penyakit menular yang disebabkan oleh jenis virus coroa yang baru ditemukan pertamakali di Wuhan, Tiongkok, pada Desember 2019. Virus corona merupakan suatu kelompok virus yang menyebabkan penyakit pada hewan atau manusia. Virus corona dapat menyebabkan infeksi salurann pernafasan pada manusia seperti batuk pilek hingga menyebabkan masalah yang lebih serius yaitu Middle East Respiratory Syndrome (MERS) dan Severe Acute Respiratory Syndrome (SARS). Di Indonesia pemerintah menetapkan berbagai peraturan guna meminimalisir penularan virus corona. Menurut peraturan Menteri Kesehatan No. 9 Tahun 2020 yang ditetapkan pada 3 April 2020, kebijakan PSBB tersebut adalah: 1) Peliburan sekolah dan tempat kerja; 2) Pembatasan kegiatan keagamaan; 3) Pembatasan kegiatan di tempat/fasilitas umum; 4) Pembatasan kegiatan sosial budaya; 5) Pembatasan moda transportasi; dan 6) Pembatasan kegiatan lainnya terkait aspek pertahanan dan keamanan. Peraturan tersebut memberikan dampak khususnya bagi industri food \& beverage, karena adanya pembatasan jumlah pengunjung, pengurangan jam operasional, dan penurunan jumlah pembeli akibat tidak sedikit orang yang pendapatannnya menurun pada saat pandemi covid-19 sehingga mengurangi konsumsinya. Hal tersebut akan memberikan dampak turunnya pendapatan usaha, pendapatan usaha yang terus menurun akan mengancam keberlangsungan suatu usaha. 
Oleh karena itu sangat penting bagi wirausaha untuk menetapkan strategi yang tepat untuk mengatasi penurunan pendapatan akibat pandemi covid-19.

Salah satu industry food \& beverage yang juga terkena dampak pandemi covid-19 adalah BS Coffee \& Donuts. BS Coffee \& Donuts merupakan usaha yang tergolong dalam umkm, pada tahun lalu BS Coffee \& Donuts sempat tutup dan hanya melayani pembelian yang bersifat take away karena adanya larangan pemerintah untuk meniadakan pembelian yang bersifat dine-in atau makan di tempat yang menyebakan penurunan pendapatan. Namun BS Coffee \& Donuts masih bisa bertahan dan menjalankan usaha ditengah pandemi covid-19 dan ketat persaingan terbukti dengan tidak pernah sepinya pengunjung yang melakukan pesanan dine-in maupun take away walau adanya pembatasan jumlah pengunjung dan pengurangan jam operasional. Dari situ dapat kita lihat BS Coffee \& Donuts memiliki strategi yang baik untuk mempertahankan usahnya di tengah pandemi covid-19 dan ketatnya persaingan.

Menurut Lassar et al (1995) Salah satu strategi yang dapat dilakukan dalam membentuk long term relationship antara perusahaan produsen dengan konsumen adalah dengan membangun dan mengelola ekuitas merek secara tepat (Bakti, 2016). Adapun dimensi ekuitas merek yang meliputi a) Kinerja merek; b) Citra merek; c) Nilai yang diterima konsumen; d) Kepercayaan konsumen; e) Perasaan pribadi tehadap merek. Dalam hal ini citra merek baik sangat penting untuk dimiliki suatu usaha karena akan mempengaruhi keputusan pembelian konsumen dan menimbulkan rasa kepercayaan konsumen akan suatu merek atau produk yang dia beli. Membangun citra merek yang baik dapat melalui program marketing dan pelayanan terhadap konsumen yang unik dan menonjol yang membedakan dengan produk lain. Selain memiliki citra merek yang baik untuk menarik minat beli konsumen strategi pemasaran dalam bentuk promosi memiliki peran penting dalam menarik minat beli konsumen. Kotler dan Keller (2007:24) dalam (Lasander, 2013) mendiskripsikan bahwa promosi adalah cara yang digunakan perusahaan untuk mengomunikasikan produk dan manfaatnya kepada masyarakat atau konsumen. Promosi dapat dibagi menjadi dua yaitu promosi periklanan dapat dilakukan dengan menggunakan media sosial, browser dan promosi penjualan dengan membuat promosi lansung kepada pembeli dan diskon.

Penelitian yang dilakukan oleh (Kuinang1 et al., 2018) menunjukan bahwa citra merek memiliki pengaruh positif dan signifikan terhadap pengambilan keputusan konsumen. Hal tersebut bertetangan dengan penelitian dari (Lubis \& Hidayat, 2017) yang 
menyatakan bahwa secara parsial citra merek tidak berpengaruh terhadap keputusan pembelian. Dalam penelitian yang dilakukan oleh (Syamsidar \& Soliha, 2019) dinyatakan bahwa promosi pengaruh positif dan signifikan terhadap keputusan pembelian. Hasil penelitian tersebut bertentangan dengan penelitian yang dilakukan oleh (Malardy \& Sari, 2015) yang menunjukan bahwa promosi secara parsial tidak memiliki pengaruh yang signifikan terhadap keputusan pembelian.

Berdasarkan pertentangan penelitian diatas maka dibutuhkan penelitian lebih lanjut mengenai bagaimana citra merek dan promosi mempengaruhi keputusan pembelian. Oleh karena itu penelitian ini akan meneliti tentang bagaimana pengaruh citra merek dan promosi terhadap keputusan pembelian produk BS Coffee \& Donuts pada masa pandemi covid-19.

\section{TINJAUAN PUSTAKA}

Citra Merek

Menurut Tjiptono(2008) dalam Amilia (2017), yang dimaksud dengan citra merek (brand image)adalah deskripsi tentang asosiasi dan keyakinan konsumen terhadap merek tertentu. Rangkuti (2004:43) dalam Fandyanto \& Kurniawan (2019) mendefinisikan citra merek merupakan kumpulan asosiasi merek yang tergambar dalam benak konsumen. Asosiasi merek adalah segala hal yang berkaitan dengan ikatan yang mengenai suatu merek. Asosiasi ini merupakan atribut yang ada di dalam merek tersebut. Berbagi asosiasi yang diingat konsumen dapat dirangkai sehingga membentuk kesan terhadap merek (brand image).

Sedangkan dimensi - dimensi utama yang membentuk citra merek menurut Kotler Keller (2015) dalam Rudi (2017) menyatakan bahwa terdapat dimensi-dimensi utama yang membentuk citra merek yaitu sebagai berikut:

\section{Brand Identity}

Merupakan identitas fisik yang berkaitan dengan merek atau produk tersebut sehingga pelanggan mudah mengenali dan membedakannya dengan merek atau produk lain, seperti logo, warna, kemasan, lokasi, identitas perusahaan yang memayungi, slogan, dan lain-lain. 


\section{Brand Personality}

Diartikan sebagai karakter khas sebuah merek yang membentuk kepribadian tertentu sebagaimana layaknya manusia, sehingga khalayak pelanggan dengan mudah membedakannya dengan merek lain dalamkategori yang sama, misalnya karakter tegas, kaku, berwibawa, nigrat, atau murah senyum, hangat, penyayang, berjiwa sosial, atau dinamis, kreatif, independen, dan sebagainya.

\section{Brand Association}

Meliputi hal-hal spesifik yang pantas atau selalu dikaitkan dengan suatu merek, bisa muncul dari penawaran unik suatu produk, aktivitas yang berulang dan konsisten misalnya dalam hal sponsorship atau kegiatan social resposibility, isuisu yang sangat kuat berkaitan dengan merek tersebut, ataupun person, simbolsimbol dan makna tertentu yang sangat kuat melekat pada suatu merek.

4. Brand Attitude and Behavior

Merupakan sikap atau perilaku komunikasi dan interaksi merek dengan pelanggan dalam menawarkan benefit-benefit dan nilai yang dimilikinya. Attitude and behavior mencakup sikap dan perilaku pelanggan, aktivitas dan atribut yang melekat pada merek saat berhubungan dengan khalayak pelanggan, termasuk perilaku karyawan dan pemilik merek.

5. Brand Benefit and Competence

Adalah nilai-nilai dan keunggulan khas yang ditawarkan oleh suatu merek kepada pelanggan yang membuat pelanggan dapat merasakan manfaat karena kebutuhan, keinginan, mimpi, dan obsesinya terwujudkan oleh apa yang ditawarkan tersebut.

Adapun indikator-indikator yang mencirikan citra merek menurut Freddy Rangkuti (2009:44) dalam Qonita, (2018):

\section{Recognition (Pengenalan)}

Tingkat dikenalnya sebuah merek oleh konsumen, jika sebuah merek tidak dikenal maka produk dengan merek tersebut harus dijual dengan mengandalkan harga termurah seperti pengenalan logo, tagline, desain produk maupun hal lainnya sebagai identitas dari merek tersebut.

2. Reputation (Reputasi)

Merupakan suatu tingkat reputasi atau status yang cukup tinggi bagi sebuah merek karena lebih memiliki track record yang baik, sebuah merek yang disukai konsumen akan lebih mudah dijual dan sebuah produk yang dipersepsikan 
memiliki kualitas yang tinggi akan mempunyai reputasi yang baik. Seperti persepsi dari konsumen dan kualitas produk.

3. Affinity (Daya tarik)

Merupakan Emotional Relationship yang timbul antara sebuah merek dengan konsumennya hal tersebut dapat dilihat dari harga, kepuasan konsumen dan tingkat asosiasi.

4. Loyality (kesetiaan)

Menyangkut seberapa besar kesetiaan konsumen dari suatu produk yang menggunakan merek yang bersangkutan.

Subagyo (2010:129) dalam Suryani (2016) menyatakan bahwa promosi merupakan seluruh kegiatan yang dimaksudkan untuk menyampaikan atau mengkomunikasikan suatu produk kepada pasar sasaran, untuk memberi informasi tentang keistimewaan, kegunaan dan yang paling penting adalah tentang keberadaannya, untuk mengubah sikap ataupun untuk mendorong orang untuk bertindak dalam membeli suatu produk. Promosi penjualan merupakan kunci utama dalam pemasaran, yang bersifat jangka pendek dan dirancang untuk menarik pembelian produk atau layanan tertentu dengan lebih cepat oleh konsumen atau perdagangan menurut (Kotler \& Keller, 2016 dalam (Pramezwary et al., 2021)). Kotler dan Amstrong menjelaskan bahwa promosi memiliki tujuan yang luas (Kotler dan Amstrong, 2001:174 dalam Sholihat (2019)), yang meliputi:

1. Meningkatkan penjualan

2. Mendorong pembelian

3. Mendapatkan pelanggan baru

Menurut ( Kotler, Philip, et al., 2012 dalam (Rudi, 2017)), bauran promosi terdiri atas 5 (lima) dimensi promosi, yaitu:

1) Advertising. Semua bentuk presentasi dan promosi non personal yang dibayar oleh sponsor untuk mempresentasikan gagasan, barang atau jasa.

2) Sales promotion. Insentif-insentif jangka pendek untuk mendorong pembelian atau penjualan suatu produk atau jasa.

3) Personal selling. Presentasi personal oleh tenaga penjualan dengan tujuan menghasilkan penjualan dan membangun hubungan dengan konsumen. 
4) Public relations. Membangun hubungan supaya memperoleh publisitas yang menguntungkan, membangun citra perusahaan yang bagus, dan menangani atau meluruskan rumor, cerita, serta event yang tidak menguntungkan.

5) Direct marketing. Hubungan langsung dengan sasaran konsumen dengan tujuan untuk memperoleh tanggapan segera dan membina hubungan yang abadi dengan konsumen. Bentuk promosi yang digunakan mencakup catalogs, telephone marketing, kiosks, internet, mobile marketing, dan lainnya.

Keputusan Pembelian

Keputusan pembelian merupakan bagian dari prilaku konsumen yang merujuk pada prilaku membeli konsumen akhir yang membeli barang atau jasa untuk konsumsi pribadi(Sholihat, 2019). Setiap hari konsumen dihadapkan pada berbagai pilihan barang atau jasa, dan mengharuskan konsumen untuk memutuskan barang atau jasa apa yang akan mereka beli atau konsumsi. Menurut Kotler, (2004: 291) dalam Sholihat (2019) ada beberapa indikator dalam pengambilan keputusan pembelian, yaitu:

a. Kemantapan pada sebuah produk, yaitu kemantapan keyakinan pelanggan dalam memilih suatu produk yang produk yang akan dibeli nya.

b. Kebiasaan dalam membeli produk, yaitu kebiasaan konsumen untuk membeli produk yang sama, karena produk tersebut telah sesuai dengan apa yang diharapkannya.

c. Memberikan rekomendasi kepada orang lain, yaitu kesedian konsumen untuk merekomendasikan produk yang telah dirasakannya kepada teman atau keluarga , baik dari segi pelayanan yang memuaskan ,ataupun manfaat yang di dapat dari pembelian produk tersebut.

d. Melakukan pembelian ulang, yaitu kesedian konsumen untuk datang dan membeli kembali produk yang telah mereka beli dan rasakan kualitas nya.

Terdapat 5 proses dalam pengambilan keputusan pembelian menurut Kotler dan Keller (2002) dalam (Syamsidar \& Soliha, 2019) yaitu:

1. Pengenalan masalah, merupakan proses pembelian yang dimulai saat pembeli mengenali sebuah masalah atau kebutuhan.

2. Pencarian informasi, yang merupakan proses dimana konsumen telah tergugah kebutuhannya dan terdorong untuk mencari informasi atas kebutuhan yang diinginkannya. 
3. Evaluasi alternatif, yang mana konsumen menggunakan informasi untuk sampai pada sejumlah pilihan merek akhir. Evaluasi alternatif yaitu bagaimana konsumen memproses informasi untuk sampai pada pilihan merek.

4. Keputusan pembelian, merupakan keputusan konsumen dalam menentukan peringkat merek dan membentuk niat pembelinya. Pada umumnya keputusan pembelian konsumen adalah membeli merek yang paling disukai.

5. Perilaku pascapembelian, merupakan rasa puas atau tidak puas setelah konsumen membeli produk.

\section{METODE PENELITIAN}

Metode yang digunakan dalam penelitian ini adalah deskriptif. Nazir (2010:55) dalam Mulyawan \& Sidharta (2013) menyatakan bahwa metode deskriptif adalah menerangkan hubungan, menguji hipotesis, membuat prediksi serta mendapatkan makna implisit dari suatu masalah yang ingin dipecahkan. Di dalam penelitian ini yang menjadi populasinya adalah orang yang pernah mengkonsumsi produk BS Coffee \& Donuts. Penentuan sample pada penelitian ini didasarkan pada dua kriteria yaitu orang yang pernah membeli produk BS Coffee \& Donuts dan bersedia untuk mengisi kuisioner yang disebarkan oleh peneliti. Variabel dalam penelitian ini dioperasionalkan sebagai berikut:

\begin{tabular}{|c|c|c|}
\hline $\begin{array}{c}\text { Konsep/Fokus } \\
\text { pertanyaan }\end{array}$ & Indikator & Daftar Pertanyaan \\
\hline \multirow{3}{*}{$\begin{array}{c}\text { Citra Merek } \\
\text { (Freddy Rangkuti } \\
\text { 2009:44 dalam } \\
\text { (Qonita, 2018)) }\end{array}$} & 1. Recognition (Pengenalan) & $\begin{array}{l}\text { 1) Produk apa saja yang } \\
\text { ditawarkan BS Coffee \& } \\
\text { Donuts? } \\
\text { 2) Dimana letak BS Coffee \& } \\
\text { Donuts? } \\
\text { 3) Bagaimana interior BS Coffee } \\
\text { \& Donuts? }\end{array}$ \\
\hline & 2. Reputation (Reputasi) & $\begin{array}{l}\text { 1) } \begin{array}{l}\text { Menurut anda bagaimana } \\
\text { kualitas produk yang }\end{array} \\
\text { ditawarkan oleh BS Coffee \& } \\
\text { Donuts? } \\
\text { 2) Apakah anda pernah kecewa } \\
\text { dengan BS Coffee \& Donuts? } \\
\text { 3) Pernahkan anda mengajukan } \\
\text { complaint? Bagaimana respon } \\
\text { staff BS Coffee \& Donuts? }\end{array}$ \\
\hline & 3.Affinity (Daya tarik) & $\begin{array}{l}\text { 1) Menurut anda apakah harga } \\
\text { yang ditetapkan BS Coffee \& } \\
\text { Donuts sesuai dengan kualitas } \\
\text { produknya? } \\
\text { 2) Apa yang paling membuat } \\
\text { anda ingin kembali lagi ke BS } \\
\text { Coffee \& Donuts? }\end{array}$ \\
\hline
\end{tabular}




\begin{tabular}{|c|c|c|}
\hline $\begin{array}{c}\text { Konsep/Fokus } \\
\text { pertanyaan }\end{array}$ & Indikator & Daftar Pertanyaan \\
\hline & & $\begin{array}{l}\text { 3) Menurut anda apakah fasilitas } \\
\text { yang diberikan BS Coffee \& } \\
\text { Donuts sudah membuat anda } \\
\text { nyaman? } \\
\text { 4) Apa yang membedakan produk } \\
\text { BS Coffee \& Donuts dengan } \\
\text { cafe lain? }\end{array}$ \\
\hline & 4. Loyality (kesetiaan) & $\begin{array}{l}\text { 1) Seberapa sering anda } \\
\text { melakukan pembelian ulang } \\
\text { di BS Coffe \& Donuts? } \\
\text { 2) Apakah anda ingin } \\
\text { merekomendasikan BS Coffee } \\
\text { ke teman-teman anda? }\end{array}$ \\
\hline \multirow{3}{*}{$\begin{array}{c}\text { Promosi } \\
\text { (Kotler dan } \\
\text { Amstrong, 2000 dalam } \\
\text { (Ernestivita, 2016)) }\end{array}$} & 1. Advertising (Periklanan) & $\begin{array}{l}\text { 1) Dari mana anda mengetahui } \\
\text { BS Coffee \& Donuts? } \\
\text { 2) Pernahkah anda melihat iklan } \\
\text { BS Coffee \& Donuts? } \\
\text { 3) Menurut anda bagaimana iklan } \\
\text { yang diberikan oleh BS Coffee } \\
\text { \& Donuts di media sosial? }\end{array}$ \\
\hline & $\begin{array}{l}\text { 2. Sales Promotion (Promosi } \\
\text { Penjualan ) }\end{array}$ & $\begin{array}{l}\text { 1) Menurut anda bagaimana } \\
\text { promosi yang di berikan BS } \\
\text { Coffee \& Donuts baik promosi } \\
\text { melalui aplikasi pemesanan } \\
\text { makanan maupun pemesanan } \\
\text { secara langsung? }\end{array}$ \\
\hline & $\begin{array}{l}\text { 3. Personal Selling (Penjualan } \\
\text { Perseorangan) } \\
\text { 4. Direct Marketig (Pemasaran } \\
\text { Langsung) }\end{array}$ & $\begin{array}{l}\text { 1) Menurut penilaian anda } \\
\text { bagaimana pelayanan yang di } \\
\text { berikan oleh BS Coffee \& } \\
\text { Donuts? }\end{array}$ \\
\hline
\end{tabular}

\section{HASIL DAN PEMBAHASAN}

Dari penyebaran kuisioner yang dilakukan oleh peneliti maka didapatkannya 41 responden yang sesuai dengan kriteria yang telah ditentukan. Adapun jawaban yang diperoleh dari penyebaran kuisioner tersebut adalah sebagai berikut:

\section{Variabel Citra Merek}

\section{A. Indikator Recognition (Pengenalan)}

1. Produk apa saja yang ditawarkan BS Coffee \& Donuts?

41 responden mengerti dan mampu menjelaskan produk yang dijual BS Coffee \&

Donuts. Adapun prosentase dari jawaban responden digambarkan dalam grafik

Pie Chart: 


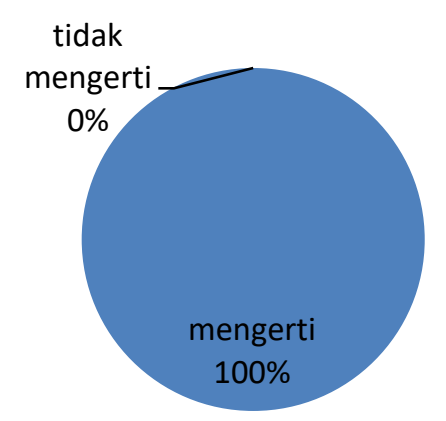

Gambar 1. Pie Chart responden yang mengerti produk ditawarkan BS Coffee $\&$ Donuts

2. Dimana letak BS Coffee \& Donuts?

41 responden mengetahui letak atau lokasi dari BS Coffee \& Donuts. Adapun prosentase dari jawaban responden digambarkan dalam grafik Pie Chart:

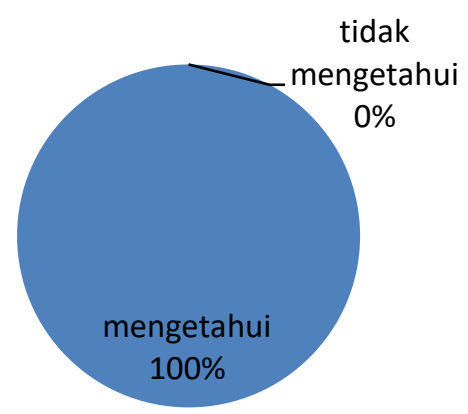

Gambar 2. Pie Chart responden yang mengetahui letak BS Coffee \& Donuts

3. Bagaimana interior BS Coffee \& Donuts?

41 responden mengerti dan mampu menjelaskan bagaimana interior BS Coffee \& Donuts. Adapun prosentase dari jawaban responden digambarkan dalam grafik Pie Chart:

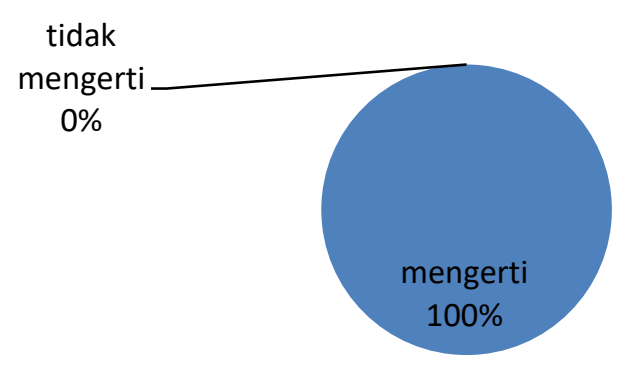

Gambar 3. Pie Chart responden yang mengerti bagaimana interior BS Coffee $\&$ Donuts. 
B. Indikator Reputation (Reputasi)

1. Menurut anda bagaimana kualitas produk yang ditawarkan oleh BS Coffee \& Donuts?

21 responden menyatakan bahwa kualitas produk BS Coffee \& Donuts sudah baik dan sisanya 21 responden menyatakan bahwa kualitas produknya sangat baik. Adapun prosentase dari jawaban responden digambarkan dalam grafik Pie Chart:

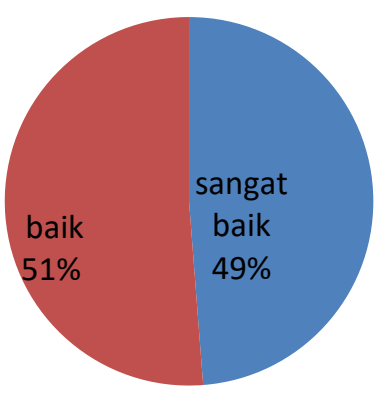

Gambar 4. Pie Chart kualitas produk BS Coffee \& Donuts

2. Apakah anda pernah merasa kecewa dengan BS Coffee \& Donuts?

41 responden menyatakan belum pernah merasa kecewa dengan BS Coffee \& Donuts. Adapun prosentase dari jawaban responden digambarkan dalam grafik Pie Chart:

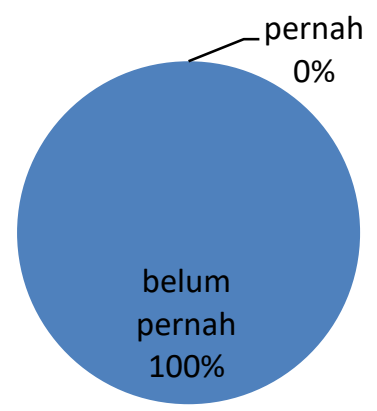

Gambar 5. Pie Chart responden yang pernah merasa kecewa dengan BS Coffee \& Donuts.

3. Pernahkan mengajukan complaint? Bagaimana respon staff BS Coffee \& Donuts? 40 responden menyatakan bahwa belum pernah mengajukan complaint dan sisanya 1 responden menyatakan sudah pernah mengajukan complaint dan 
diberikan respon baik oleh staff BS Coffee \& Donuts. Adapun prosentase dari jawaban responden digambarkan dalam grafik Pie Chartz :

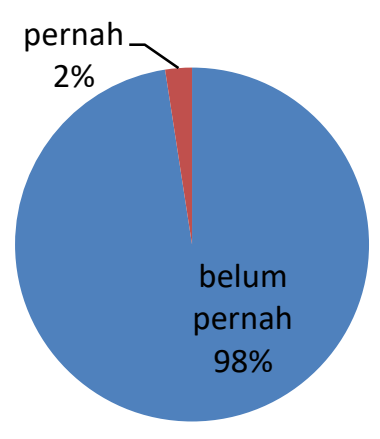

Gambar 6. Pie Chart responden yang pernah mengajukan complaint kepada BS Coffee \& Donuts.

C. Indikator Affinity (Daya tarik)

1. Menurut anda apakah harga yang ditetapkan BS Coffee \& Donuts sesuai dengan kualitas produknya?

41 responden menyatakan harga yang ditetapkan BS Coffee \& Donuts sudah sesuai dengan kualitas yang diberikan. Adapun prosentase dari jawaban responden digambarkan dalam grafik Pie Chartz:

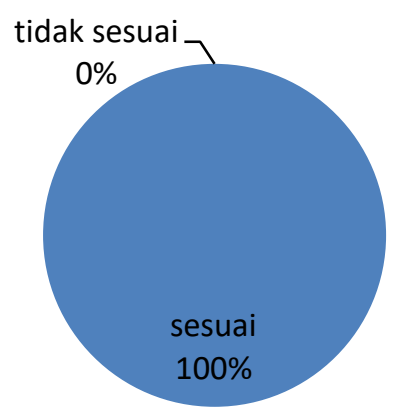

Gambar 7. Pie Chart responden yang menyatakan harga yang ditetapkan BS Coffee \& Donuts sesuai dengan kualitas produknya.

2. Apa yang paling membuat anda ingin kembali lagi ke BS Coffee \& Donuts?

41 responden menyatakan alasan yang membuat mereka ingin kembali ke BS Coffee \& Donuts adalah karena produk makanan dan minuman BS Coffee \& Donuts. 
3. Menurut anda apakah fasilitas yang diberikan BS Coffee \& Donuts sudah membuat nyaman?

41 responden menyatakan bahwa fasilitas yang diberikan oleh BS Coffee \& Donuts sudah membuat mereka nyaman. Adapun prosentase dari jawaban responden digambarkan dalam grafik Pie Chartz :

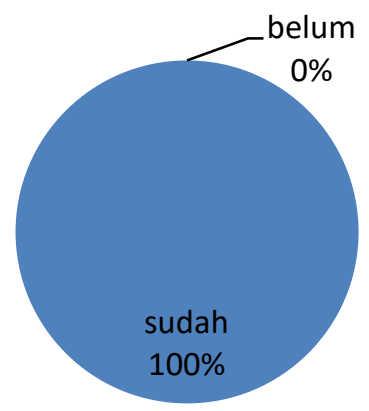

Gambar 8 . Pie Chart responden yang menyatakan harga yang ditetapkan BS Coffee \& Donuts sesuai dengan kualitas produknya

4. Apa yang membedakan produk BS Coffee \& Donuts dengan cafe lain?

41 responden menyatakan bahwa yang membedakan produk BS Coffee \& Donuts dengan cafe lain adalah produk yang berkualitas namun harganya sangat terjangkau.

D. Indikator Loyality (kesetiaan)

1. Seberapa sering anda melakukan pembelian ulang di BS Coffee \& Donuts? 22 responden menyatakan sering melakukan pembelian ulang dan 19 responden menyatakan tidak terlalu sering. Adapun prosentase dari jawaban responden digambarkan dalam grafik Pie Chartz:

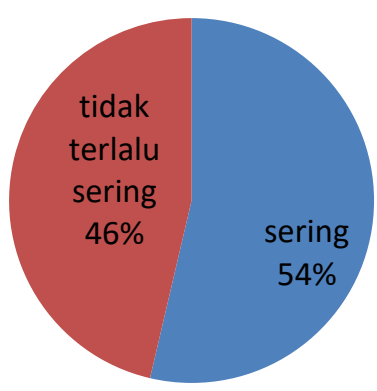

Gambar 9. Pie Chart responden yang sering melakukan pembelian ulang pada BS Coffee \& Donuts. 
2. Apakah anda ingin merekomendasikan BS Coffee \& Donuts ke teman-teman anda?

41 responden menyatakan ingin merekomendasikan BS Coffee \& Donuts kepada teman-temanya. Adapun prosentase dari jawaban responden digambarkan dalam grafik Pie Chartz :

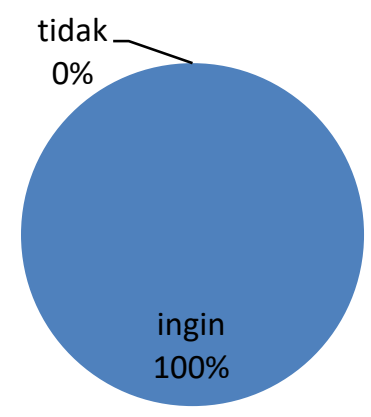

Gambar 10 . Pie Chart responden yang ingin merekomendasikan BS Coffee \& Donuts kepada teman-temannya.

\section{Variabel Promosi}

A. Indikator Advertising (Periklanan)

1. Dari mana anda mengetahui BS Coffee \& Donuts?

18 responden menyatakan mengetahui BS Coffee \& Donuts dari rekomendasi orang terdekat, dan 23 responden lainnya mengetahui dari media sosial. Adapun prosentase dari jawaban responden digambarkan dalam grafik Pie Chartz:

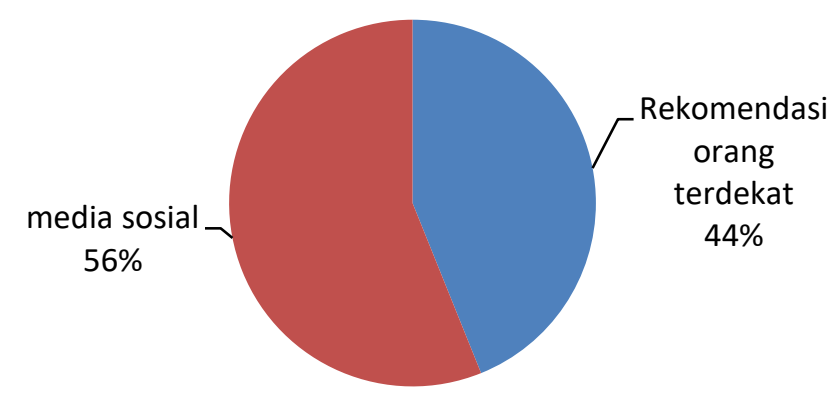

Gambar 11 . Pie Chart sumber responden mengetahui BS Coffee \& Donuts.

2. Pernahkah anda melihat iklan BS Coffee \& Donuts?

37 responden menyatakan pernah melihat iklan BS Coffee \& Donuts, dan sisanya 4 responden menyatakan belum pernah. Adapun prosentase dari jawaban responden digambarkan dalam grafik Pie Chartz : 


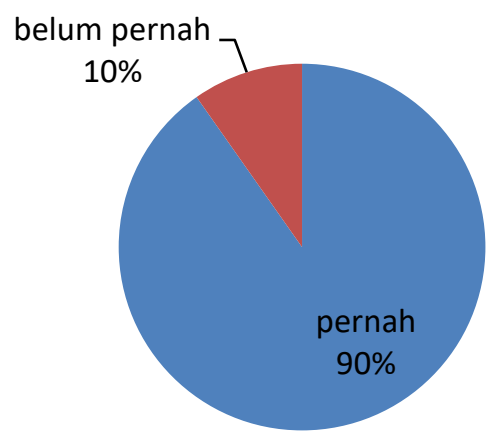

Gambar 12 . Pie Chart responden yang pernah melihat iklan BS Coffee \& Donuts.

3. Menurut anda bagaimana iklan yang diberikan oleh BS Coffee \& Donuts di media sosial?

37 responden menyatakan bahwa iklan yang diberikan oleh BS Coffee \& Donuts menarik dan sisanya 4 responden menyatakan tidak tau karena belum pernah melihatnya. Adapun prosentase dari jawaban responden digambarkan dalam grafik Pie Chartz :

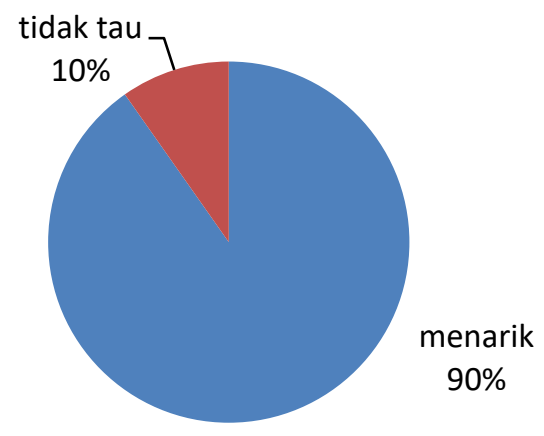

Gambar 13. Pie Chart tanggapan responden terkait iklan yang diberikan BS Coffee \& Donuts.

B. Indikator Sales Promotion (Promosi Penjualan)

1. Menurut anda bagaimana promosi yang di berikan BS Coffee \& Donuts baik promosi melalui aplikasi pemesanan makanan maupun pemesanan secara langsung?

41 responden menyatakan bahwa promosi yang diberikan BS Coffee \& Donuts menarik. Adapun prosentase dari jawaban responden digambarkan dalam grafik Pie Chartz : 


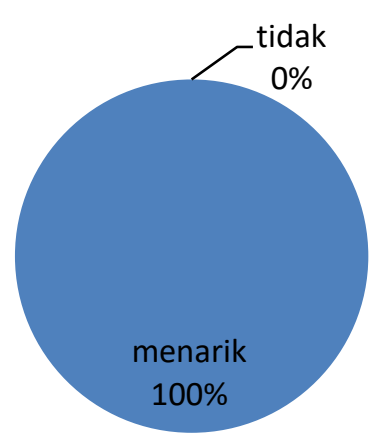

Gambar 14 . Pie Chart tanggapan responden terkait promosi yang diberikan BS Coffee \& Donuts.

C. Indikator Personal Selling (Penjualan Perseorangan) dan Direct Marketing (Pemasaran Langsung)

1. Menurut penilaian anda bagaimana pelayanan yang di berikan oleh BS Coffee \& Donuts?

41 responden rata-rata menyatakan bahwa pelayanan yang diberikan oleh BS Coffee \& Donuts baik dan juga pelayanannya ramah. Adapun prosentase dari jawaban responden digambarkan dalam grafik Pie Chartz :

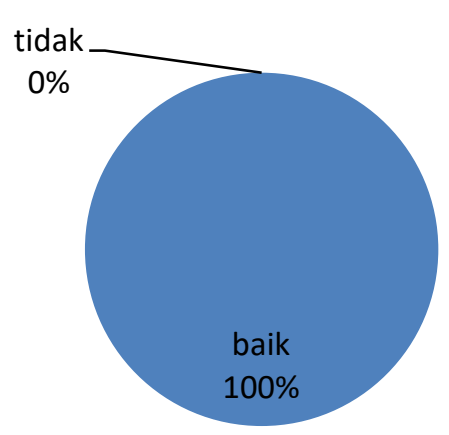

Gambar 15 . Pie Chart tanggapan responden terkait pelayanan yang diberikan BS Coffee \& Donuts.

\section{SIMPULAN DAN REKOMENDASI}

Dari hasil penelitian diatas maka dapat dianalisis bahwa variabel citra merek dan promosi merupakan faktor penting yang mempengaruhi keputusan pembelian konsumen BS Coffee \& Donuts. Hal tersebut dibuktikan dari hasil jawaban responden yang merupakan konsumen BS Coffee \& Donuts yang menyatakan bahwa BS Coffee \& Donuts telah mampu memberikan citra merek yang baik dimata konsumen yang mana secara keseluruhan citra merek BS Coffee \& Donuts telah memenuhi empat indikator yaitu 
recognition (pengenalan), reputation (reputasi), affinity (daya tarik), loyality (kesetiaan). Selain itu pada variabel promosi juga didapatkan hasil yang sama, pada indikator promosi yang meliputi advertising (periklanan), sales promotion (promosi penjualan), personal selling (penjualan perseorangan), dan direct marketing (pemasaran langsung) rata-rata jawaban responden menyatakan bahwa promosi menjadi salah satu faktor yang mempengaruhi keputusan pembelian di BS Coffee \& Donuts.

\section{DAFTAR PUSTAKA}

Amilia, S. (2017). Pengaruh Citra Merek, Harga, dan Kualitas Produk terhadap Keputusan Pembelian Handphone Merek Xiaomi di Kota Langsa. Jurnal Manajemen Dan Keuangan Unsam, 6(1), 660-669.

Bakti, S. (2016). Pengaruh Ekuitas Merek Terhadap Minat Beli Ulang Pada Kedai Kopi Black Canyon Mall Jamtos. Jurnal Manajemen Terapan Dan Keuangan, 5(1), 3648. https://online-journal.unja.ac.id/mankeu/article/view/3233

Ernestivita, G. (2016). Analisis Pengaruh Place, Promotion, Dan People Terhadap Keputusan Konsumen Melakukan Pembelian Produk Pasar Modal Dengan Menggunakan Jasa Equity Brokerage Di Pt Sucorinvers Central Gani Cabang Kediri. Jurnal Nusamba, l(2).

Fandyanto, R., \& Kurniawan, R. (2019). Pengaruh Kepercayaan Merek Dan Citra Merek Terhadap Minat Beli Ulang “Kopi Toraja” Di Coffee Josh Situbondo. Jurnal Ilmiah Ilmu Ekonomi Dan Bisnis, 7(1), 21-42.

Kuinang1, L. D., Moniharapon2, S., \& Soegoto3, A. S. (2018). Pengaruh Kebutuhan, Gaya Hidup, Dan Citra Merek Terhadap Pengambilan Keputusan Konsumen Di Warung Kopi Van Ommen Coffee Manado. Jurnal EMBA: Jurnal Riset Ekonomi, Manajemen, Bisnis Dan Akuntansi, 6(3), 1238-1247. https://doi.org/10.35794/emba.v6i3.20180

Lasander, C. (2013). Citra Merek, Kualitas Produk, Dan Promosi Pengaruhnya Terhadap Kepuasan Konsumen Pada Makanan Tradisional. Jurnal Riset Ekonomi, Manajemen, Bisnis Dan Akuntansi, 1(3), 284-293. https://doi.org/10.35794/emba.v1i3.2024

Lubis, D. I. D., \& Hidayat, R. (2017). Pengaruh Citra Merek dan Harga terhadap Keputusan Pembelian pada Sekolah Tinggi Ilmu Manajemen Sukma Medan. Jurnal Ilman, 5(1), 15-24. https://doi.org/10.4135/9781412983907.n1598

Malardy, M. A., \& Sari, D. (2015). Pengaruh Bauran Pemasaran Jasa Terhadap Keputusan Pembelian Konsumen (Studi Kasus Konsumen Siete Cafe \& Garden Bandung). Jurnal Ilmiah Manajemen Kesatuan, 2(2), 1-8. 
Mulyawan, A., \& Sidharta, I. (2013). ANALISIS DESKRIPTIF PEMASARAN JASA DI STMIK MARDIRA INDONESIA BANDUNG. Computech \& Bisnis, 7(1), 18.

Pramezwary, A., Juliana, J., Winata, J., Tanesha, R., \& Armando, T. (2021). Brand Trust dan Promosi Penjualan Terhadap Keputusan Pembelian Produk Di Masa Covid-19. Jurnal Perspektif, 19(1), 24-31. https://doi.org/10.31294/jp.v19i1.9376

Qonita, A. (2018). Analisis Pengaruh Iklan, Celebrity Endorser, Dan Citra Merek Terhadap Minat Beli Wardah Kosmetik (Survei Pada Calon Konsumen Wardah Kosmetik Complek Pondok Pesantren Mulungan Wetan, Mlati, Sleman, DIY). Jurnal Ekobis Dewantara, 1(8).

Rudi, G. (2017). Studi Pustaka Faktor Yang Mempengaruhi Keputusan Pembelian: Harga, Promosi, Kepercayaan, Citra Merek Dan Kualitas Produk Pada Toko Online Gudanggrosiran.Com. Journal of Chemical Information and Modeling, 53(9), 2125. https://doi.org/10.38035/JMPIS

Sholihat, A. (2019). Pengaruh Promosi Penjualan Dan Kualitas Pelayanan Terhadap Keputusan Pembelian Di Krema Koffie. Journal of Chemical Information and Modeling, 53(9), 4.

Suryani, H. W. (2016). Analisis Pengaruh Promosi Terhadap Peningkatan Penjualan Sparepart Pada Pt Aksara Motor Medan. Ilmiah Integritas, 2(1), 1-13.

Syamsidar, R., \& Soliha, E. (2019). Kualitas Produk, Persepsi Harga, Citra Merek dan Promosi terhadap Proses Keputusan Pembelian. Jurnal Bisnis Dan Ekonomi, 26(2), 146-154. 